\title{
低温下におけるコンクリートのひずみ挙動と劣化
}

\section{DEFORMATION AND DETERIORATION OF CONCRETE AT LOW TEMPERATURES}

\author{
三浦尚*·李 道憲** \\ By Takashi MIURA and Do Heun LEE
}

\begin{abstract}
Under low temperature, some concrete structures suffer serious deterioration. This may be due to the ice formation in concrete micropores, which causes microcracking and induces volume changes of concrete. Based on this observation, we investigated deterioration of concrete subjected to cyclic cooling and heating of various temperature ranges. The two major findings are: (1) residual strain of concrete is in good correlation to its relative dynamic modulus of elasticity and (2) there are well-defined temperature ranges which determine the progress of deterioration. Qualitative and quantitative analyses will be made on these observations.
\end{abstract}

Keywords : deformation, deterioration, cyclic temperature, expansion, contraction

\section{1.はじめに}

コンクリート構造物の必要条件の 1 つは耐久的でなけ ればならないことである.しかし，コンクリートはさま ざまな条件によって耐久性を失っていく，そのうちの 1 つに，構造物が常温と低温の繰り返しを受けて劣化する 場合が考えられ，実際，このような環境にさらされる寒 冷地での構造物はたくさん存在している. また，寒冷地 でない地域においても同様な作用を受ける低温構造物は 数多く建設されつつある.

低温構造物の代表的なものとしては，現在われわれの 生活になくてはならないほど密接な関係をもっている， 液化天然ガス (LNG) や液化石油ガス (LPG) の貯蔵 タンクおよび輸送キャリア，また，それらの二次的な構 造物などが挙げられる，一方では，超伝導に関する研究 が活発に進んでおり，液体窒素温度程度の低温で安定し た高温超伝導物質が得られるようになってきている，超 伝導を利用して電力を貯蔵するためには，超伝導体で 作ったコイルを極低温に保つための容器や極低温物質を

* 正会員 工博 東北大学教授 工学部土木工学科 （９９80 仙台市青葉区荒巻字青葉）

** 学生会員 工修 東北大学大学院 工学部土木工学科 (同上)
貯蔵するための設備などが必要とされ，その材料として， 経済的および性質的に適したコンクリートが使用される 可能性が高いと考えられる。このような低温構造物は設 計上特別な配慮を必要とし，使用材料としてのコンク リートの極低温下における挙動に関する知識や情報はき わめて重要である.

低温におけるコンクリートの物性は, 常温のときと比 べてかなり異なり，温度が低下するにつれて大きく変化 する．このような物性の変化は主にコンクリート中の水 が凍結することによって起こる. コンクリートは温度が 下がると収縮または膨張の大変複雑な体積変化をし, 常 温亡低温の繰り返しを受けると，凍結時に生じたマイク ロクラックによってコンクリートの内部組織が緩んで劣 化する，実際の構造物が受ける温度変化の範囲は，寒冷 地における気温の変化や低温構造物におけるいろいろな 条件によって，広範囲にわたってさまざまであり，その ときの劣化のメカニズムは大変複雑になる．しかし，極 低温までの温度の繰り返しを受けたコンクリートの劣化 に関する著者らや Rostásy らの研究結果によれば1,2), 約 $-50^{\circ} \mathrm{C}$ 以下の温度では劣化に関連すると思われるコ ンクリートの大きな膨張はみられないことから, 本研究 では主として常温からー70 $\mathrm{C}$ の間で繰り返し温度範囲 を変えてコンクリートの劣化を調べた．特に，劣化の中 
でも一般の凍害とは異なり, コンクリートに外部から水 が供給されない場合の劣化を対象とすることにした。ま た, 今回の研究では第 1 段階としてこの種の劣化の性状 を明らかにすることを主目的としたため，使用したコン クリートは劣化しやすい Non-AEコンクリートとした. さらに，コンクリート構成要素がコンクリート全体の劣 化によ゙のような役割をするかは劣化のメカニズムの把握 において重要であると考えられ，コンクリート構成要素 それぞれのひずみ挙動を測定し, 各要素がコンクリート 全体の劣化に及ぼす影響について検討した。

\section{2. 実験材料および実験方法}

実験に用いたセメントは早強ポルトランドセメント, 細骨材は宮城県白石川産川砂 (比重：2.56, FM : 2.89), 粗骨材は宮城県丸森産砕石（比重：2.86, FM : 6.92) である.また，本研究に用いたコンクリートの配合を Table 1 に示すが, モルタル, ペーストはそれぞれコン クリートと同じ配合のものである. Fig. 1 に実験の手順

Table 1 Mix Proportions of Concrete.

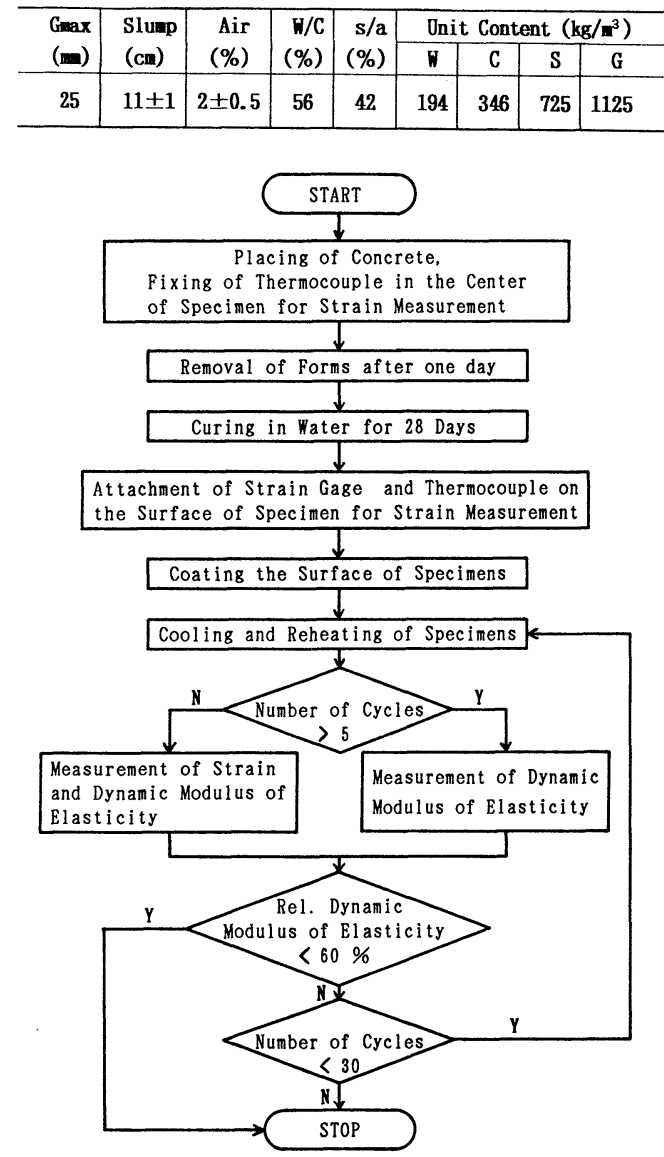

Fig. 1 Flow Chart of Testing Procedure.
を示し, Fig. 2 にはコンクリートおよびモルタル, ペー ストのひずみ測定用供試体の形状・寸法，また，ひずみ ゲージおよび熱電対の位置を示す。一方，動弾性係数測 定用のコンクリート供試体はひずみ測定用と形状および 寸法が同じである.

供試体のひずみ測定は供試体の両側面にひずみゲージ を貼り付けてディジタルひずみ測定器を用いて行った. 本研究ではかなり低い温度まで測定範囲となっているの で，予備実験を行ってひずみゲージがー $70^{\circ} \mathrm{C}$ まで安定 性を保つことを確認するとともに各温度での補正值を求 めておき，ひずみの測定值をそれぞれのひずみゲージの 温度によって補償した。一方, 以下の図中で用いた Average Strain とは供試体の両側面に貼り付けた 2 枚 のひずみゲージの平均值である.

本実験では外部から水の供給がない場合のコンクリー トの劣化を調べるため, 試験中の含水量の損失がないよ うに供試体の表面にコーティングを施した。使用した コーティング剂はゴム系のものであり，しかも供試体に コーティングしたときの厚さは $0.3 \mathrm{~mm}$ 程度に過ぎない ので，コーティング剤がコンクリートのひずみに及ぼす 影響は無視してよいものと考えられる. 一方，一般の液 状のコーティング剂は低温下で使用されると固くなり収 縮するケースが多く，それによってコーティング剤がひ びわれたり剝がれたりすることがある．本実験で使用し たコーティング剤においても供試体を冷却した際にひび われたり剝がれたりすることがあったが，10サイクル まではほぼそのような損傷は生じなく，それ以降も欠陥 が生じた際にその部分を補修することによって試験中の 含水量の損失を最低限にした. その結果, 30 サイクル 後の含水量の変化量を養生直後の含水量の約 $2 \%$ 以下 に抑えることができた。

供試体の冷却および加熱は超低温恒温恒湿器を使用 し, 空気中で行った。試験時の最大冷却速度は約 $0.35^{\circ} \mathrm{C} / \mathrm{min}$, 最大加熱速度は約 $0.90^{\circ} \mathrm{C} / \mathrm{min}$ であった。 冷却時における供試体の中心と表面との最大温度差はコ

(a) Concrete Specimen

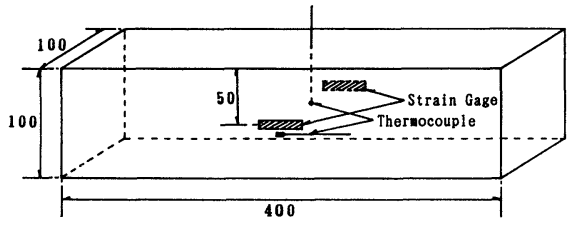

(b) Mortar and Paste Specimen

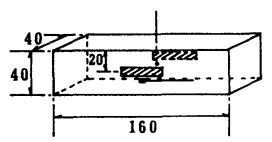

Fig. 2 Prism Specimens for Strain Measurement. 


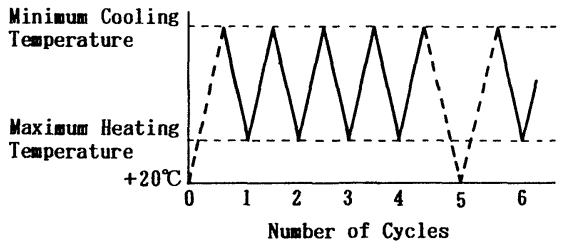

Fig. 3 Temperature Cycle for Specimen.

ンクリート供試体においては約 $5^{\circ} \mathrm{C}$, モルタルおよび ペースト供試体においては約 $2^{\circ} \mathrm{C}$ であった.しかし， 冷却・加熱によって変化する供試体の温度は表面・中心 ともにそれぞれ同じ温度範囲になることを確認した。ま た，ここで測定した温度ひずみは，供試体の形を考えて 平均温度に対するひずみであると考えることができる. また，コンクリートの平均温度は，供試体中の温度分布 を調べた予備実験の結果から，実際の供試体の中心と表 面温度を用いて計算によって求められた。

コンクリートの劣化は，養生後表面をコーティングし た供試体に Fig. 3 のような所定温度範囲（すなわち，冷 却最低温度から加熱最高温度まで）の繰り返しを与え， 供試体の中心温度が常温になったところで非破壊試験を 行い，動弾性係数を測定することによって調べられた。 実験は相対動弾性係数が $60 \%$ を割るまで行い，60\% を割らない供試体については 30 サイクルまで行った。

\section{3. 実験結果および考察}

\section{（1） 概 説}

前述したように，コンクリートの凍害は水の凍結によ る影響が最も大きい. しかし，コンクリート中の細孔水 は必ずしも $0^{\circ} \mathrm{C}$ で凍るのではなく，それよりはるかに 低い温度まで水として存在することがある．Tognon は 熱量計を用いた実験より，セメントペースト中の自由水 の凍結がー $4{ }^{\circ} \mathrm{C}$ から $-90^{\circ} \mathrm{C}$ の間で徐々に起こることを 確認した ${ }^{31}$.このような水点降下の原因は, 細孔水がア ルカリのような水溶性の物質を含んでいることや, 細孔 内で起こる水分子と細孔壁との間の表面エネルギーの相 互作用などによる ${ }^{4)}$. また, 水点降下は細孔径の関数で あり，細孔が小さいほよ゙氷点も低い，Zech らはこのよ うな水点と細孔径との関係を調べた5!．彼らの計算值を Fig. 4 の上部に示し，下部には本研究で用いたコンク リートの細孔分布の一例を示す.ここで, 細孔構造は水 銀圧入法で調べたものであり，全細孔量に対する各細孔 の量をパーセンテージで表わした．この図より，本研究 で用いたコンクリート中には直径 $1000 \AA$ 以下の非常に 小さい細孔がたくさん含まれており，全細孔量の約 80 \%を占めていることがわかる. また，凍結点が細孔径 に関係することから, 繰り返し温度範囲の違いによって 凍結する量が決定され, 劣化の程度にも影響があると考
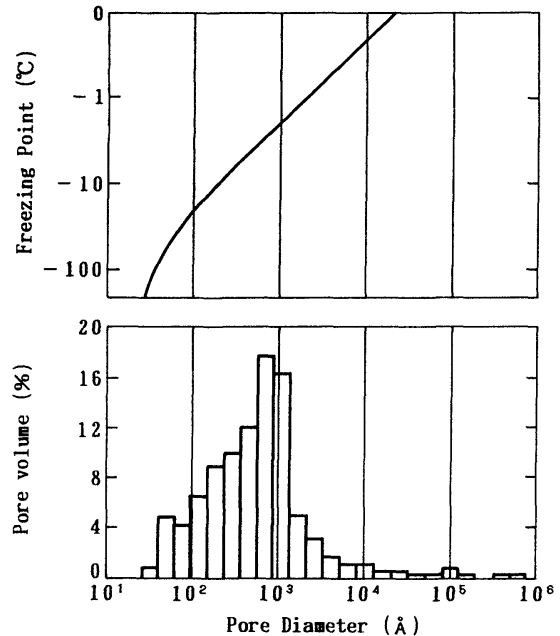

Fig. 4 Relation Between Pore Diameter and Freezing Point.

えられる。ただし，氷点降下と細孔径の関係については いろいろな研究者らの間で多少の差があり，実験に用い た供試体の性質および成分または実験方法などによって もその值は異なってくるはずである.それに,コンクリー 卜中の水分はある温度までは温度が低下しても凍らない まま水として存在することがあり，このような過冷却に よっても凍結点は低下することになる。これらの理由よ り，あるサイズの細孔の水が必ずしも Fig. 4 に示すよう な温度で凍ることはないものである.

このようなコンクリート中に含まれているさまざまな サイズの細孔水は凍結によって約 $9 \%$ の体積膨張をし, コンクリートの内部組織を破壊するが，結果としてコン クリート全体の体積膨張を引き起こす。したがって，コ ンクリートの劣化を把握するのにおいて，ひずみの挙動 は重要な情報を与えることになる. Fig. 5 はコンクリー トを常温からー $196^{\circ} \mathrm{C}$ まで冷却したときのひずみの挙動. を示す"1). この図より, コンクリートは温度の低下とと もに収縮または膨張を示し，不可逆的なひずみ挙動を示 すが，約一 $70^{\circ} \mathrm{C}$ 以下では直線的に収縮するだけである. 実際には一 $70^{\circ} \mathrm{C}$ 以下であってもコンクリートを構成す

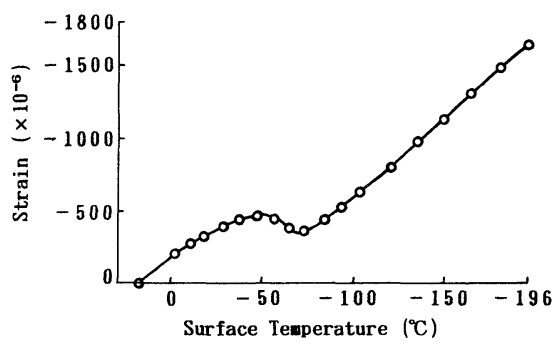

Fig. 5 Typical Relation Between Strain and Surface Temperature. 
るそれぞれの成分の線膨張係数が異なるために温度低下 に伴い元応力は大きくなると思われるが，ひずみ挙動が 本質的に線形的で，また可逆的である ${ }^{1,6)}$ ことからコン クリートの劣化に及ぼす影響はほとんどないものと考え られる.したがって, $-70^{\circ} \mathrm{C}$ 以下の温度においては, 温度が低下することによりコンクリートがさらに劣化す ることはあまりないと考えられ，本研究では常温から一 $70^{\circ} \mathrm{C}$ の間でコンクリートが受ける繰り返し温度範囲の 最低温度と最高温度をいろいろ变えてひずみの挙動や劣 化を検討することにした。

\section{（2）最低温度の違いによる影響}

コンクリート構造物はいろいろな温度範囲の繰り返し を受けることがあり，その温度範囲の違いによる劣化へ の影響を研究するためにはコンクリートのひずみ挙動を 詳細に知る必要がある。それゆえ Fig.6(a) のように, 常温からー70 $\mathrm{C}$ まで 5 回の繰り返しを与えたときの Non-AE 湿潤コンクリートのひずみ挙動を調べた。こ の図より，コンクリートは冷却に伴って収縮するが約一 $20^{\circ} \mathrm{C}$ から $-50^{\circ} \mathrm{C}$ の間で急激な膨張を示し，それ以下の 温度では再び収縮を示すことがわかる．このときコンク リートの膨張は劣化の原因となると考えられるのでコン クリートの劣化に影響を及ぼす温度範囲は約一 $20^{\circ} \mathrm{C}$ $-50^{\circ} \mathrm{C}$ と推定される．以上のことから，本研究では第 一段階として繰り返し温度範囲の最低温度を $-20^{\circ} \mathrm{C}$ か らー70ㄷ の間で変え, ひずみ挙動や劣化への影響を調 ベることにした．まず，Fig.6(a) のようなコンクリー

(a) Cyclic Temperature Range : $+4^{\circ} \mathrm{C} \sim-70^{\circ} \mathrm{C}$

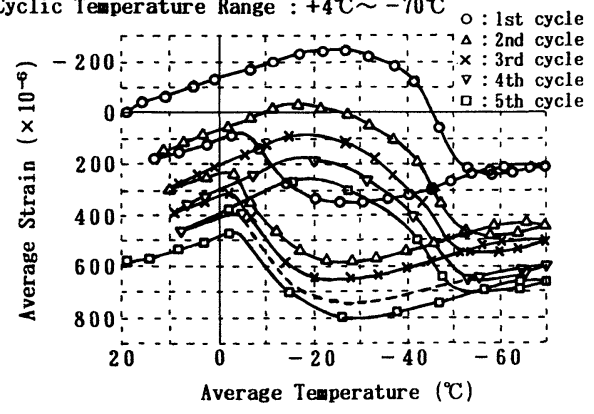

(b) Cyclic Temperature Range : $+4^{\circ} \mathrm{C} \sim-50^{\circ} \mathrm{C}$ o: lst cycle

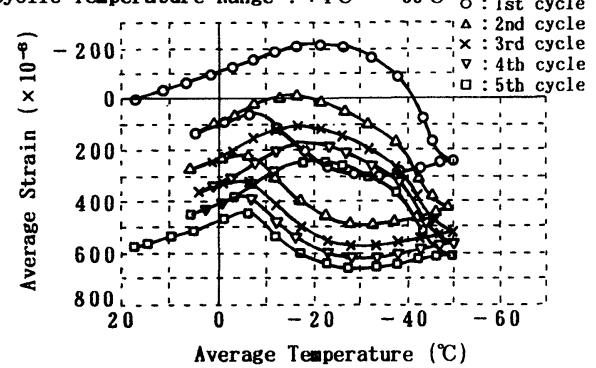

Fig. 6 Relation Between Strain and Temperature for Various Minimum Cooling Temperatures.
トの典型的なひずみ挙動については，すでにいろいろ報 告されており7),8)，そのメカニズムについてはまだ論争 中であるが，これからの温度範囲の違いによる影響を調 べるのに重要であるので，次のようにその特徴的な点を 述べる。

a) 冷却時の $+20^{\circ} \mathrm{C}$ から約 $-20^{\circ} \mathrm{C}$ までにおいて，コ ンクリートはほぼ線形的に収縮する。このように一 $20^{\circ} \mathrm{C}$ までも収縮することは，ある程度の水は凍ったと 思われるが，前述したような水点降下現象の影響によっ てまだたくさんの細孔水が凍っていないことを示し，ま た，水和度が $100 \%$ であってもコンクリート中には水 で満ちていない空隙が存在し ${ }^{91}$, その空隙が水から水へ 相変化する際に生じる膨張圧を吸収することにもよると 考えられる.

b) 約 $-20^{\circ} \mathrm{C}$ から約 $-50^{\circ} \mathrm{C}$ までは著しい膨張を示 す.この温度範囲ではかなり小さい細孔水まで水に相変 化することによって内部圧力が増加し，マイクロクラッ クが生じ，体積膨張が起こる．このときの膨張量はコン クリートの劣化に大きな影響を与え, 単位水量や含水量 および $W / C$ が大きいほど大きく，また，冷却速度が速

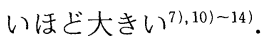

c）温度がー $50^{\circ} \mathrm{C}$ 以下になるとコンクリートは再び 膨張から収縮に転じ，ほぼ線形的な挙動を示す。Stockhausen ら ${ }^{15)}$ によると細孔半径 $30 \AA$ 以下の細孔水は一 $165^{\circ} \mathrm{C}$ までも凍らない。供試体の温度がー $50^{\circ} \mathrm{C}$ 以下に なるとゲルポアー (寸法のオーダーは $15 〜 20 \AA^{16)}$ ) よ り大きい毛細管空陌まではほとんど凍結し，コンクリー トの膨張を引き起こすほどの要因がなくなるものと考え られる。

d) 加熱時のひずみ挙動は水の水点と融点が違うこと によって凍結時とはかなり違う挙動を示し，常温に戻っ たときには残留膨張ひずみが生じる。この残留ひずみは 明らかにコンクリートの内部組織が緩んだことを示す。

一方, 繰り返し温度範囲の最低温度の違いによってコ ンクリートの劣化度は異なるので, 次は最低温度を一 $20^{\circ} \mathrm{C} \sim-70^{\circ} \mathrm{C}$ の間で変えたときの結果について述べる.

繰り返し温度範囲が常温からー50 $\mathrm{C}$ までのものであ るFig. 6(b) は，常温からー70 $\mathrm{C}$ までのものとほぼ同 様なひずみ挙動を示し, 残留ひずみや劣化度 (Fig. 8 参 照）もほぼ同じである.このように，コンクリートの膨 張はー $50^{\circ} \mathrm{C}$ のきにはほぼみえなくなり，結果的に， 最低温度がー $70^{\circ} \mathrm{C}$ 場合とほぼ同程度の膨張量と残留 ひずみを示したことになる.したがって，コンクリート のひずみ挙動が完全に直線的な挙動を示すー $50^{\circ} \mathrm{C}$ 以下 の温度はコンクリートの劣化にあまり影響しないと考え られる. 冷却時の膨張量や残留ひずみを用いて, 冷却最 低温度の違いによるコンクリートの劣化度を比較してみ 
ると, $-70^{\circ} \mathrm{C}$ や $50^{\circ} \mathrm{C}$ までのものに比べて, $-40^{\circ} \mathrm{C}$ までのものはかなり小さく, $-30^{\circ} \mathrm{C}$ までのものはそれ

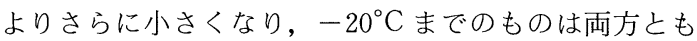
ほとんど現われなかった。この結果より，コンクリート の劣化に及ぼす繰り返し温度範囲の最低温度を 3 つの範 用に分けて考えることができる.

a）劣化に大きく影響しないー $20^{\circ} \mathrm{C}$ 以上の範囲

b）温度が低いほど劣化が大きくなるー $20^{\circ} \mathrm{C} \sim-$ $50^{\circ} \mathrm{C}$ の範囲

c）劣化とはあまり関係がないー $50^{\circ} \mathrm{C}$ 以下の範囲

このような結果から最低温度における残留ひずみ（各 サイクルでのひずみから 1 サイクル目のひずみを差し引 いた值）とサイクル数との関係を調べたものが Fig. 7 で あるが，コンクリートの残留ひずみはサイクル数が増え るにつれて大きくなり, その増分は徐々に小さくなるこ とがわかる。

コンクリートの劣化を調べるために，以上のひずみ測 定試験と同時に行った非破壊試験の結果を Fig. 8 に示 す.この結果より, $+4{ }^{\circ} \mathrm{C}$ から $-70^{\circ} \mathrm{C}$ と $-50^{\circ} \mathrm{C}$ の間を 繰り返したものの相対動弾性係数はわずか 5〜10 サイク

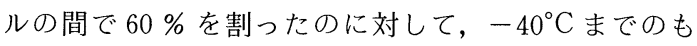

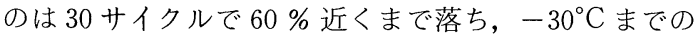
ものは 30 サイクルで約 $80 \%$ であり, $-20^{\circ} \mathrm{C}$ までのも のは優れた耐久性を示した。この非破壊試験の結果はコ

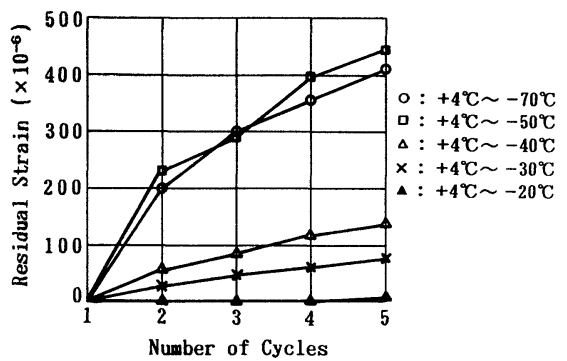

Fig. 7 Relation Between Residual Strain and Number of Cycle.

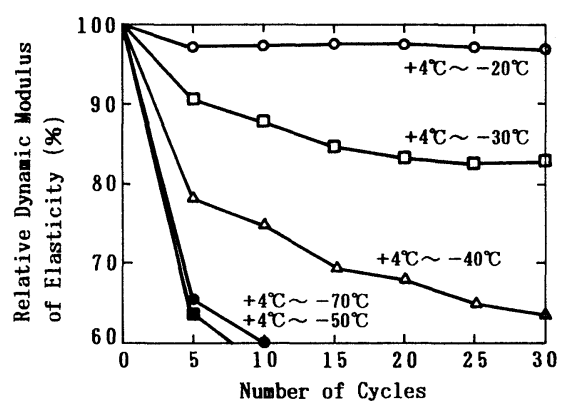

Fig. 8 Deterioration of Concrete Due to Repetition of Cooling with Fixed Maximum Temperature and Various Minimum Temperatures.
ンクリートのひずみ挙動から得られた結果と同様で, 最 低温度が低いほど劣化度が大きくなり，そして劣化に大 きく影響する範囲は約一 $20^{\circ} \mathrm{C}$ から $-50^{\circ} \mathrm{C}$ の間であると 考えられる. 最低温度が低いほど冷却時の膨張量や劣化 度が大きいことは，温度の低下とともにより小さい径の 細孔水まで凍り, 結果として, 内部圧力およびそれによ る内部組織の損傷程度が大きくなったためであると考え られる。

\section{（3）最高温度の違いによる影響}

多くの研究者らが凍害に関する研究を行ってきたが, 繰り返し温度範囲の影響を定量的に調べたことは数少な く，特に最高温度についてはほとんど見当たらない．そ れゆえ,この節では, 繰り返し温度範囲の違いがコンク リートの劣化に及ぼす影響を調べる第二段階として，構 造物が氷点下での繰り返しを受けることを想定して, 繰 り返し温度範囲の最高温度を変えて, 一度冷却した後常 温に戻さず，氷点下で繰り返したときの実験結果につい て述べる.

Fig. 9(a), (b)，(c)，(d) は繰り返し温度範囲の最低 温度を $-70^{\circ} \mathrm{C} と し$, 最高温度を $-3^{\circ} \mathrm{C},-6^{\circ} \mathrm{C},-10^{\circ} \mathrm{C}$, $-30^{\circ} \mathrm{C}$ とて繰り返したときのひずみの挙動を示す. 最高温度をこのように決めたのは，Fig. 6(a) より，加 熱時のコンクリートのひずみ挙動が約ー $30^{\circ} \mathrm{C}$ までは直 線的に膨張し, 約 $-30^{\circ} \mathrm{C} \sim-10^{\circ} \mathrm{C}$ までは急激に収縮し, 約 $-10^{\circ} \mathrm{C}$ 以上では再び線形的に膨張を示すことに基づ く.その結果, 最高温度がー $3^{\circ} \mathrm{C}$ の場合はサイクル数が 増えるに従ってひずみの挙動が膨張側に平行移動した形 で変化し, 残留ひずみが増えていくことがわかる. しか し, 最高温度が- $6{ }^{\circ} \mathrm{C}$ の場合にはサイクル数が増えても ひずみの挙動はあまり変わらず, $-10^{\circ} \mathrm{C}$ と $-30^{\circ} \mathrm{C}$ の場 合にはサイクル数が増えてもひずみ挙動は同じヒステリ シスを示す.したがって，加熱時の最高温度が劣化に影 響を及ぼす範囲は約 $-10^{\circ} \mathrm{C}$ から水がすべて解ける温度

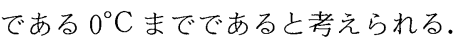

一方，ひずみ測定試験と同様の結果が動弾性係数試験 から得られた。Fig. 10 は繰り返し温度範囲の最高温度 を変えたときの相対動弾性係数を調べたものである.こ れらの值はFig. 3 に示すようなサイクルをかけたため, 氷点下での繰り返しによる影響だけを調べるためには, Fig. 3 の点線の部分の影響を除かなければならない.そ のために+20 $\mathrm{C}$ からー70 $\mathrm{C}$ まで繰り返した点線部分だ けの影響を Fig. 10 において点線で示し, 基準線とした. つまり，基準線より下の方にあることは，水点下だけの 温度範囲の繰り返しが劣化に影響していることである. この基準を用いると, 繰り返し温度範囲の最高温度が高 いほど劣化しているようであるが, $-30^{\circ} \mathrm{C},-10^{\circ} \mathrm{C},-$ $6{ }^{\circ} \mathrm{C}$ ののは基準線と比べてほぼ同じであり, $-3{ }^{\circ} \mathrm{C}$ と 
(a) Cyclic Temperature Range : $-3^{\circ} \mathrm{C} \sim-70^{\circ} \mathrm{C}$

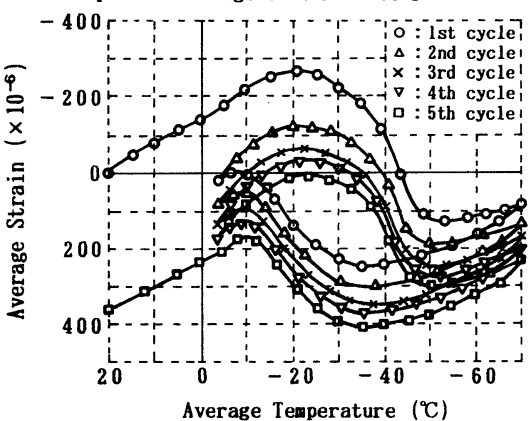

(b) Cyclic Temperature Range : $-6^{\circ} \mathrm{C} \sim-70^{\circ} \mathrm{C}$

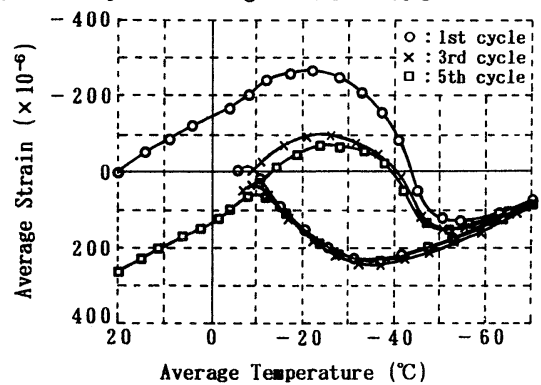

(c) Cyclic Temperature Range : $-10^{\circ} \mathrm{C} \sim-70^{\circ} \mathrm{C}$

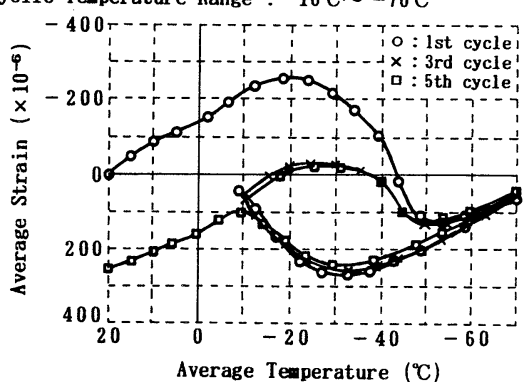

(d) Cyclic Temperature Range : $-30^{\circ} \mathrm{C} \sim-70^{\circ} \mathrm{C}$

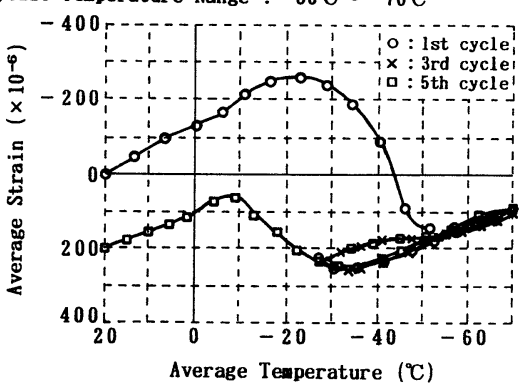

Fig. 9 Relation Between Strain and Temperature for Various Maximum Heating Temperatures.

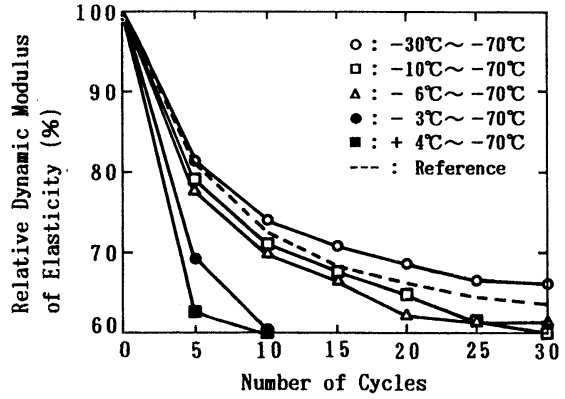

Fig. 10 Deterioration of Concrete Due to Repetition of Cooling with Fixed Maximum Temperature and Various Maximum Temperatures.

$+4^{\circ} \mathrm{C}$ のものは基準線よりかなり低く, 著しく劣化して いることがわかる.

以上の結果をみると，コンクリートの劣化はコンク リート中の水が凍結時に膨張することによると考えられ ていたが，必ずしもそれだけではないようである。この ことは Fig. 9(b) より明らかである。すなわち， $-10^{\circ} \mathrm{C}$ まで加熱した後再び凍結したときコンクリートは大きく 膨張したのにもかかわらず，サイクル数が増えてもひず み挙動は同じで残留ひずみは生じなく，また，劣化も起 こらなかった．したがって，本研究の結果からみると， コンクリートの膨張は劣化に影響する場合としない場合 があると考えられる．このことは，温度の上昇とともに
より小さい細孔の水から解けていくが， $-10^{\circ} \mathrm{C}$ まで上 昇したときには移動するような水はまだ解けていないた めではないかと考えられる，すなわち，温度変化を繰り 返すに従って高温時ではコンクリートの中で解けた水の 移動が起こり，それが冷却時に凍結することによって劣 化はさらに進行するものと考えられるのである.

モルタルに対して実験を行った他の研究者らの結果に よると ${ }^{4), 10)}, W / C$ が違っても収縮から膨張へ，または， 膨張から収縮へ転ずる境界点がほとんど同様であった が, その際, 当然 $W / C$ が違うことによって細孔分布や 孔の量は変わったと考えられる ${ }^{9}$. すなわち, 細孔分布 や量が変わってもひずみ挙動の境界点はあまり変化しな いということができる．したがって，劣化に大きく影響 を及ぼす繰り返し温度範囲は，本研究で得られた結果が コンクリートの配合によって大きく変わることはあまり ないと考えられる. しかし，コンクリートのひずみ変化 に影響する水点降下は細孔径の関数であるので細孔分布 や量によって, 劣化の程度は大きく異なるものと思われ る.

\section{（4）材料別のひずみ挙動}

コンクリートは主に水，セメント，骨材の 3 つの材料 で作られ，コンクリートとしての構成要素は骨材とセメ

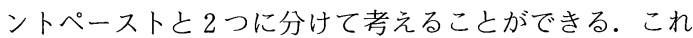
らの構成要素それぞれがコンクリートの劣化にどのよう に影響するかを調べるためには，まず，構成要素それぞ 


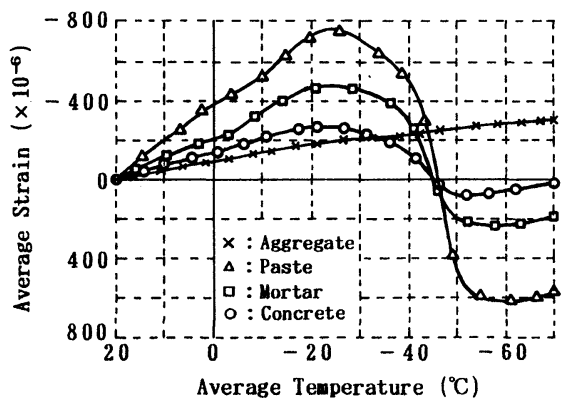

Fig. 11 Relation Between Strain and Temperature of Concrete Constituents.

れの劣化について調べる必要がある. その理由から, こ こでは, 骨材, および同じ $W / C$ のペースト, モルタル, コンクリートと 4 種類に分けて, 湿潤状態のそれぞれの ひずみ挙動を調べることによってコンクリートの劣化に 及ぼす影響を判断することにした，ただし，ペースト供 試体は $W / C$ が高いほど材料分離が起こりやすいのでそ の影響をなるべく小さくするため, ひずみの測定は,

Fig. 2 のように供試体中央部で行い, 供試体の平均的な 值として用いた.

Fig. 11 はコンクリートを構成しているそれぞれの要 素に対する 1 サイクル目の冷却時のひずみ挙動を示す. この図よりモルタルやペーストのひずみ挙動はコンク リートのひずみ挙動と性質的に同じ傾向を示すことがわ かる. Fig. 11 から得られた線膨張係数と冷却時の最大 膨張量および 5 サイクル後の残留ひずみの結果を Table 2 に示す. Fig. 11 と Table 2 より冷却時の最大膨張量や 残留ひずみはコンクリート, モルタル, ペーストの順に 大きくなり，骨材はまったく膨張を示さなかった．この ことは, コンクリートのひずみ挙動は主にペーストに よって左右されることを示し，コンクリート中のペース トの体積割合によってひずみ挙動や劣化度が大きく違っ てくると考えられる.

また, 骨材とペーストの界面の破壊については, 収縮 または膨張するときの線膨張係数の違いで知ることがで きる. 本研究で用いた砕石は良質のもので，また，かな り密実な内部構造をしていたため, 骨材のひずみ挙動は 線形的であり，残留ひずみを示さず，骨材自体の劣化に

Table 2 Properties of Concrete Constituents.

\begin{tabular}{|c|c|c|c|c|}
\hline \multirow{2}{*}{$\begin{array}{l}\text { Type of } \\
\text { concrete } \\
\text { constituent }\end{array}$} & \multicolumn{2}{|c|}{$\begin{array}{l}\text { Coefficient of } \\
\text { thermal expansion } \\
\qquad\left(\times 10^{-6} / \mathrm{C}\right)\end{array}$} & \multirow{2}{*}{$\begin{array}{l}\text { Maximuin } \\
\text { expansion } \\
\left(\times 10^{-6}\right)\end{array}$} & \multirow{2}{*}{$\begin{array}{l}\text { Residual } \\
\text { strain } \\
\text { after the } \\
\text { 5th cycle } \\
\left(\times 10^{-6}\right) \\
\end{array}$} \\
\hline & $-10^{\circ} \mathrm{C}$ & $-45^{\circ} \mathrm{C}$ & & \\
\hline Aggregate & 4.6 & 3.0 & - & 0 \\
\hline Paste & 17.5 & -122.9 & 1367 & 908 \\
\hline Mortar & 13.0 & -66.9 & 703 & 582 \\
\hline Concrete & 6.9 & -25.7 & 376 & 445 \\
\hline
\end{tabular}

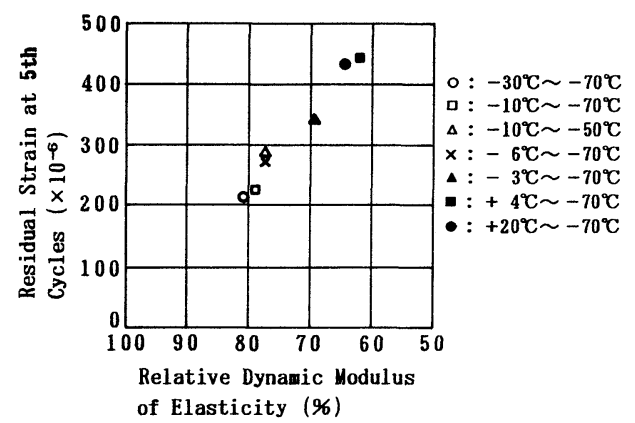

Fig. 12 Correlation Between Residual Strain and Relative Dynamic Modulus of Elasticity.

よるコンクリートの劣化はほとんどないと考えられる.

したがって，コンクリートの劣化にはペーストと骨材 との界面の影響とペーストの劣化との 2 つが主に影響し ていると考えられ，ペーストが耐久的であるようにその 性質を変える（例えば, $W / C$ の減少, 含水量の減少,

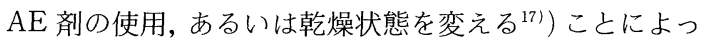
てコンクリートの劣化が改善できると考えられる.

\section{(5) 総合的考察}

コンクリートのひずみ挙動と劣化とがどのような関係 にあるかを調べるために, 繰り返し温度範囲の最高温度 の違いによる影響を調べた結果を用いて，+20ㄷ ける 5 サイクル後の残留ひずみと相対動弾性係数との関 係をFig. 12 に示してみると, 両者はほぼ直線関係にあ $り^{18), 19)}$ 強い相関関係を示す。このような結果はコンク リートの劣化を調べるのにおいてひずみの挙動は適切な パラメーターであることを示し, 供試体の最大膨張と残 留膨張は凍害を評価するのによいパラメーターであると いう MacInnis らの結果と一致する ${ }^{20)}$.

繰り返し温度範囲の違いによる劣化を次の Fig. 13, 14, 15, 16 に示す. Fig. 13 は $+20^{\circ} \mathrm{C}$ における 5 サイク ル後の残留ひずみと繰り返し温度範囲の最低温度との関 係を示し, Fig. 14 は各サイクルでの相対動弾性係数と 繰り返し温度範囲の最低温度との関係を示す。この 2 つ

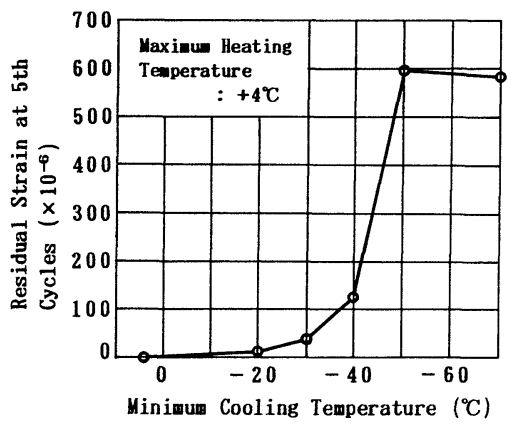

Fig. 13 Relation Between Residual Strain and Minimum Cooling Temperature. 


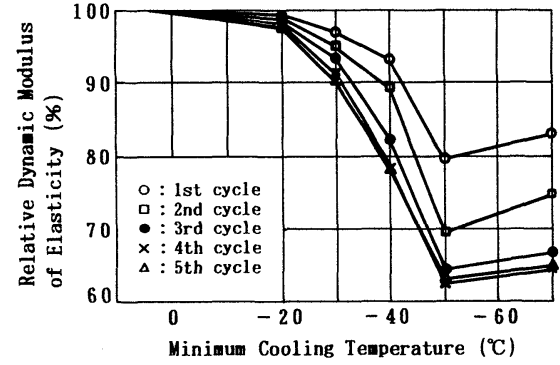

Fig. 14 Relation Between Relative Dynamic Modulus of Elasticity and Minimum Cooling Temperature.

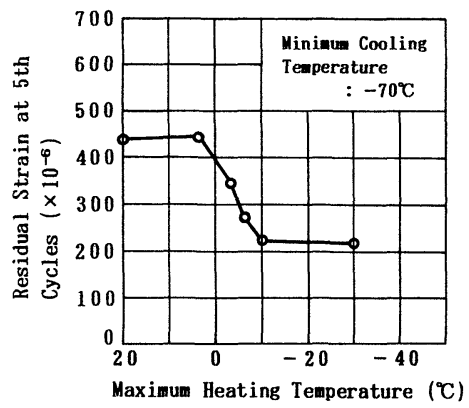

Fig. 15 Relation Between Residual Strain and Maximum Heating Temperature.

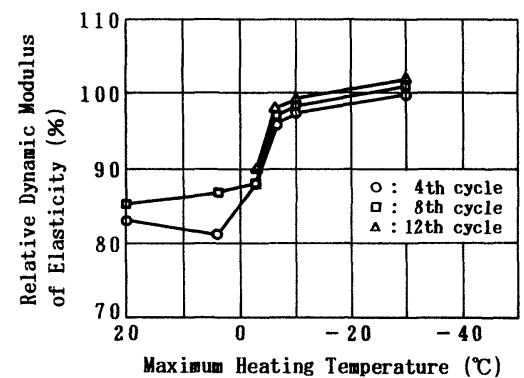

Fig. 16 Relation Between Relative Dynamic Modulus of Elasticity and Maximum Heating Temperature.

の図から温度変化の下限值が劣化に大きく影響する範囲 は約 $-20^{\circ} \mathrm{C} \sim-50^{\circ} \mathrm{C}$ のかなり広い範囲にわたるが，そ のうち， $-40^{\circ} \mathrm{C} \sim-50^{\circ} \mathrm{C}$ の範囲は注目すべき影響を及 ぼしているようである。Fig. 15 は+ $20^{\circ} \mathrm{C}$ における 5 サ イクル後の残留ひずみと繰り返し温度範囲の最高温度と の関係を示す。また，Fig.16の縦軸は，氷点下での繰 り返しだけによる劣化を Fig. 10 における基準線とそれ ぞれの相対動弾性係数との差で示し，横軸には繰り返し 温度範囲の最高温度を示す. Fig. 15, 16 より, 温度変化 の上限值が劣化に大きく影響する範囲は約 $-10^{\circ} \mathrm{C} \sim 0^{\circ} \mathrm{C}$ のようであり，かなり狭い範囲となっている。

Fig. 17 は，構造物が繰り返し冷却されたときを想定 して，コンクリートの劣化に及ぼす繰り返し温度範囲の

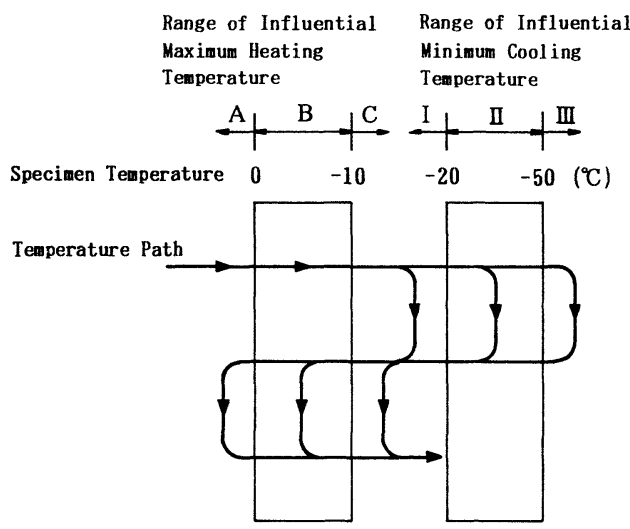

Degree of Concrete Deterioration

\begin{tabular}{|c|c|c|c|c|}
\hline \multicolumn{2}{|c|}{$\begin{array}{l}\text { Range of } \\
\text { Raximum Temperature } \\
\text { Temperature } \\
\text { Taxime of Minimum }\end{array}$} & $\begin{array}{c}\mathrm{I} \\
(\text { over } \\
-20 \mathrm{C}) \\
\end{array}$ & $\begin{array}{c}\text { II } \\
\left(\begin{array}{c}-20 \mathrm{C} \\
\sim \\
-50^{\circ} \mathrm{C}\end{array}\right) \\
\end{array}$ & $\begin{array}{c}\text { III } \\
\text { ( below } \\
\left.-50^{\circ} \mathrm{C}\right)\end{array}$ \\
\hline $\mathrm{A}$ & ( over $0^{\circ} \mathrm{C}$ ) & 0 & $\Delta$ & $x$ \\
\hline B & $\left(0^{\circ} \mathrm{C} \sim-10^{\circ} \mathrm{C}\right)$ & 0 & $\Delta$ & $\Delta$ \\
\hline C & ( below $\left.-10^{\circ} \mathrm{C}\right)$ & 0 & 0 & 0 \\
\hline
\end{tabular}

$O$ : no deterioration

$\Delta$ : depend on the temperatures

$X$ : maximum deterioration

Fig.17 A Model for Estimating Concrete Deterioration.

影響をモデル化して示したものである．ここでは，最低 温度を範囲 I, II, III, また, 最高温度を範囲 A, B , C と 区分してコンクリートの劣化の状態を示した．まず，冷 却時の最低温度の影響において, 最低温度がー $20^{\circ} \mathrm{C}$ 以 上（範囲 I ）であ机ばコンクリートの大きな劣化は起こ らず，最低温度がー $20^{\circ} \mathrm{C} \sim-50^{\circ} \mathrm{C}$ (範囲 II ）の中に入 るとコンクリートは温度が低いほど劣化しやすくなる が， $-50^{\circ} \mathrm{C}$ 以下 (範囲 III) の場合にはいくら温度が低 くなってもさらに劣化が進行することはない，加熱時の 最高温度の影響においては, 最高温度がー $10^{\circ} \mathrm{C}$ 以下（範 囲C）であれば最低温度に関係なく劣化は起こらず，約 $-10^{\circ} \mathrm{C} \sim 0^{\circ} \mathrm{C}$ (範囲 B) の場合には温度が高いほぼ劣化

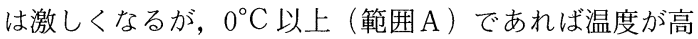
くなってもさらに劣化が進行することはない。したがっ て, 最低温度が範囲 I, または, 最高温度が範囲Cにあ る場合には大きな劣化は起こらず，最低温度と最高温度 が範囲 II と Bにある場合には最低温度が低いほざ, また， 最高温度が高いほど劣化が激しくなり, 範囲III とAの場 合には最も劣化することになる. しかし，コンクリート の劣化に影響する最高温度の範囲はかなり狭く, しかも, その間での劣化度は急激に違ってくるので，現実的には 最高温度がー $10^{\circ} \mathrm{C}$ を超えた場合に劣化が起こると判断 するのがより妥当ではないかと考えられる.

すなわち，コンクリートの温度がー $20^{\circ} \mathrm{C}$ 以下まで下 がらないようにするか，それ以下に下がった場合には再 
びー $10^{\circ} \mathrm{C}$ 以上に上がらないようにすれば良いことにな るが，そのようなコントロールができない場合には，そ れぞれの温度範囲に応じて劣化に対する配慮が必要であ る.

\section{4. まと め}

本研究では，コンクリートが低温にさらされたとき， 外部から水が供給されていない場合において常温と低温 の繰り返しによって起こる劣化に影響する温度範囲およ びコンクリートの各構成要素の影響について検討した. それらの主な結果をまとめると次のようになる。

（1）コンクリートが常温と低温の繰り返しを受けた ときに生じる残留ひずみは相対動弾性係数とほぼ直線関 係にあり, 凍害を評価するのによいパラメーターである.

（2）コンクリート構成要素の中でコンクリートの劣 化に最も影響を及ぼすのはペーストの劣化であり，ペー ストの品質を改良することによってコンクリートの劣化 も改善できると考えられる。ただし，コンクリートの劣 化を調べるにあたって，ペーストと骨材の線膨張係数の 違いによる界面の劣化も重要な影響を与えることから， 界面の問題も含めて考慮すべきであると考えられる.

（３）コンクリートの劣化は繰り返し温度範囲の違い によって大きく違ってくるが，その際，コンクリートの 劣化度は繰り返し温度範囲の最低温度と最高温度の両方 によって左右される.

a) 冷却時の最低温度がー $20^{\circ} \mathrm{C}$ 以上であるときコン クリートはあまり劣化せず， $-20^{\circ} \mathrm{C} \sim-50^{\circ} \mathrm{C}$ の場合に は温度が低いほよ゙劣化が激しくなる。また， $-50^{\circ} \mathrm{C}$ 以 下の場合には温度の低下によってさらに劣化が激しくな ることはなく，事実上劣化がそれ以上進行しない範囲で ある・

b）融解時の最高温度がコンクリートの劣化に影響を 及ぼす温度範囲は約 $-10^{\circ} \mathrm{C} \sim 0^{\circ} \mathrm{C}$ であり， $-10^{\circ} \mathrm{C}$ 以下 であれば最低温度に関係なく劣化は起こらず， $0^{\circ} \mathrm{C}$ 以上 であれば温度が高くなってもさらに劣化することはな い.

したがって，実際の構造物において，最低温度がー $20^{\circ} \mathrm{C}$ 以下になりかつ最高温度がー $10^{\circ} \mathrm{C}$ 以上になる場合 には，それぞれの温度範囲に応じてここで考えているよ うな種類の劣化に対する配慮が必要である．そしてその 具体的な対策については今後研究が行われなければなら ない.

\section{参 考 文 献}

1）三浦 尚：極低温下のコンクリートの物性，コンクリー 卜工学, Vol.22, No. 3, pp. 21 28, 1984.

2) Rostásy, F.S. and Wiedemann, G. : Stress-strain- behaviour of concrete at extremely low temperatures, Cement and Concrete Research, Vol. 10, No.4, pp. 565 $\sim 572,1980$.

3) Tognon, G. : Behaviour of mortars and concretes in the temperature range from $+20^{\circ} \mathrm{C}$ to $-196^{\circ} \mathrm{C}$, Proceedings of The Fifth International Symposium on the Chemistry of Cement, III-24, pp. 229 249, Tokyo, 1968.

4) FIP : Cryogenic behaviour of materials for prestressed concrete, Wexham Springs, pp. 84, 1982.

5) Zech, B. and Setzer, M. J. : The dynamic modulus of hardened cement paste. Part 2 : Ice formation, drying and pore size distribution, Materials and Structures, 22, pp. 125 132, 1989.

6) Elices, M., Planas, J. and Corres, H. : Thermal deformation of loaded concrete at low concrete, 2 : Transverse deformation, Cement and Concrete Research, Vol.16, No. 5, pp.741 748, 1986.

7) Miura, T. and Lee, D. H. : Deterioration of concrete subjected to repetition of cooling to $-70^{\circ} \mathrm{C}$, Review of the 42nd General Meeting, The Cement Association of Japan, pp. 190 193, 1988.

8) Planas, J., Corres, H., Elices, M. and Chueca, R. : Thermal deformation of loaded concrete during thermal cycles from $20^{\circ} \mathrm{C}$ to $-165^{\circ} \mathrm{C}$, Cement and Concrete Research, Vol. 14, No.5, pp.639 644, 1984.

9) Czernin, W. (徳根吉郎訳) : セメント・コンクリート 化学, 技報堂出版, pp. 216, 1969 .

10) Rostásy, F.S., Schneider, U. and Wiedemann, G. : Behaviour of mortar and concrete at extremely low temperatures, Cement and Concrete Research, Vol.9, No. 3, pp. 365 376, 1979.

11) Cordon, W.A. : Freezing and thowing of concretemechanisms and control, ACI Monograph, No.3, pp. 99, 1966.

12) Powers, T. C. : A working hypothesis for further studies of frost resistance of concrete, Journal of ACI, Vol.16, No. 4, pp. 245 272, 1945.

13) Goto, Y. and Miura, T. : Deterioration of concrete subjected to repetitions of very low temperatures, Transactions of the Japan Concrete Institute, pp. 183 190, 1979.

14) Koh, Y. and Kamada, E. : The behavior of concrete subjected to freezing and thawing as a reference for frost resistivity of concrete, Proceedings of The Fifth International Symposium on the Chemistry of Cement, III-99, pp. 300 315, Tokyo, 1968.

15) Stockhausen, N., Dorner, H., Zech, B. and Setzer, M. J. : Untersuchung von gefriervorgängen in zementstein mit hilfe der DTA, Cement and Concrete Research, Vol. 9, No. 6, pp. 783 794, 1979.

16) 三浦 尚：土木材料学, コロナ社, 1986.

17）三浦 尚・藤原正雄：極低温の温度変化を受けるコンク リートの劣化に関する研究，第 4 回コンクリート工学年 次講演会講演論文集，pp. 57 60, 1982.

18）李 道憲・三浦 尚：低温の繰返しを受けたコンクリー 
トの歪と劣化との関係に関する研究, 土木学会第 43 回年 次学術講演会講演概要集, 第 5 部, pp. 180 181, 1988.

19）李 道憲・ 三浦 尚・児玉浩一：繰り返し冷却されたコ ンクリートの劣化に及ぼす温度範囲の影響, 土木学会第 44 回年次学術講演会講演概要集, 第 5 部, pp. 368 369,
1989.

20) MacInnis, C. and Whiting, J. D. : The frost resistance of concrete subjected to a deicing agent, Cement and Concrete Research, Vol.9, No.3, pp. 325 336, 1979.

(1990.2.9 - 受付) 